\title{
Amnesty Initiative and the Dilemma of Sustainable Development in the Niger Delta Region of Nigeria
}

\author{
OGEGE Samuel Omadjohwoefe (Ph.D) \\ DEPARTMENT OF SOCIOLOGY, FACULTY OF THE SOCIAL SCIENCES \\ DELTA STATE UNIVERSITY, P.M.B.1, ABRAKA, DELTA STATE, NIGERIA
}

Received: May 22, 2011

Accepted: June 22, 2011

doi:10.5539/jsd.v4n4p249

\begin{abstract}
Many decades of exploration and exploitation of petroleum resources have adversely affected the host communities in the Niger Delta. Environmental degradation, loss of means of livelihood, unemployment, poverty, loss of lives and general underdevelopment characterized the region. These formidable odds that threaten the survival of the Niger Delta people triggered off various shades of interminable violent agitations by militants that involved hostage taking and attacks on oil installations. These agitations, no doubt, reduced crude oil production and had adverse effect on the national economy. This prompted the Nigerian state to intermittently launch attacks on the militants. In spite of the bombardments by the military Joint Task Force, the militants remain resolute in their agitations. Disturbed by the security and economic challenges, the Nigerian state came out with the amnesty initiative. The initiative was designed for the militants to surrender their arms, renounce militancy and also create a favourable atmosphere for the sustainable development of the region. This paper is geared towards examining theoretically, the efficacy of the amnesty initiative in finding solution to the general problem of underdevelopment in the Niger Delta. Situating the discourse within economic integration framework, the paper argues succinctly that the amnesty initiative is intentionally designed to deceitfully disarm the militants and create an enabling environment for the multinational oil companies to operate unhindered while ignoring the burning issues of underdevelopment that triggered the violent agitations in the first place. In order to avert a relapse into militancy, the Nigerian state must develop a credible rehabilitation package for the ex-militants and a holistic framework that can adequately address the problem of underdevelopment in the Niger Delta.
\end{abstract}

Keywords: Niger Delta, Oil Exploration, Environmental Degradation, Underdevelopment, Militants, Amnesty Initiative, Sustainable Development

\section{Introduction}

The Niger Delta is a region in Nigeria with various ecological zones that mainly cut across the states of Akwa Ibom, Bayelsa, Delta, Rivers with fringes in parts of Abia, Cross River, Edo, Imo, and Ondo states. The region encompasses about 60 percent of Africa's largest mangrove forests and stretches over $20,000 \mathrm{~km}^{2}$ swamp of the littoral fringes of Nigeria (Eyinla and Ukpo 2006, Afinotan and Ojakorotu 2009). The region has a population of about 28.9 million with age structure that depicts a large segment of young people below 30 years of age comprising 62.1 percent of the total population. The Niger Delta is known for its unique history of contributions to the Nigerian state from pre-colonial days till date (Ikime 2000). At present, the richly endowed region is the geographical heart of crude oil exploitation where Nigeria earns 99.7 and 90 percent of its export and annual income respectively (IMF 2003, Azaiki 2007).

In spite of the huge oil revenue derived from the region, the Niger Delta is still characterised by widespread poverty. There exists a negative relationship between abundant natural resources and development in the region. Analysis of poverty and human development in the region paints a dismal picture. The region's human development index score, a measure encompassing longevity of life, knowledge and a decent standard of living remain at abysmally low value of 0.564 (with 1 being the highest score) while this rating puts the Niger Delta at a slightly higher level than Nigeria's overall score of human development index of 0.453 , the region rates far below that of countries with similar oil and gas resources (UNDP 2006).

Beside the poor score of human development index, the living conditions in oil communities are abysmally poor, with devastated and polluted environments, destroyed livelihoods, impaired health and a destroyed social structure. The rate of environmental degradation aggravates and reinforces the problems of human insufficient livelihood and other ecological disasters. A combination of these oil induced social problems pose serious challenges to sustainable development and this constitutes an issue of utmost concern not just to the inhabitants of the region but Nigeria and the international community.

In the face of these predicaments, the Niger Delta has become a place of frustrated expectations. This has inevitably fostered a siege mentality especially among youths who feel condemned to a future without hope. As a reaction to widespread neglect, marginalization and environmental degradation, the youths adopted confrontational strategies to address the problem. This action resulted in the emergence of several militant groups who resorted to the use of sophisticated arms such as machine guns, rifles, dynamites, rocket propelled 
grenade launchers and gun boats to draw the attention of the multinational oil companies and the Nigerian state to their collective travails.

The militants' confrontational strategies find expression in high profile kidnapping of expatriates or members of their families, bombing and destruction of oil facilities as well as daring guerilla-styled attack on highly fortified military formations. The reaction disrupts oil production and undoubtedly hurt the economy through the loss of needed foreign exchange to finance sub-national and national development programmes. Disturbed by the security and economic challenges of the militants' violent agitations in the Niger Delta, the Nigerian state under the leadership of late President Umaru Musa Yar'Adua introduced the amnesty programme for the militants as a solution to the problem of general insecurity and also to create a peaceful and an enabling environment to tackle the development crisis in the region. The paper therefore assesses theoretically, the efficacy and the ability of the amnesty initiative to address the problem of underdevelopment in the Niger Delta.

\section{Amnesty: A Conceptual Framework}

Amnesty as a concept is derived from the Greek word amnestia meaning cast into oblivion or forgetfulness. This root shares with the medical term amnesia which means a loss of memory (Chigara 2002). Amnesty is defined as a strategic state policy which takes a form of executive or legislative clemency in which offenders or those involved in illegal actions are formally pardoned. Once a person or group is granted amnesty, all records of the person's accusation, trial, conviction and imprisonment must be cast into oblivion or people must lose memory of whatever atrocities the person had committed. In order words, upon amnesty, the antisocial acts of a person are totally wiped from the records and he/she is considered not only innocent but also as having no legal connection with the crime in the first place (Schey 1977).

An amnesty process in most cases is conditional. It requires the recipients to perform certain tasks such as providing information, admitting the truth about their actions, showing remorse or surrendering weapons as in the case of the militants in the Niger Delta of Nigeria. The conditional amnesty could be individualized, so that the recipients can only benefit from an amnesty programme upon successful compliance with its conditions.

Amnesty is categorized into individual amnesty, amnesty movement and mass amnesty. Individual amnesty has to do with a pardon that is extended to an offender. The amnesty movement refers to a programme in which illegal materials or contraband can be turned over to authorities with no repercussions for those who possessed the illegal materials or contraband. Mass amnesty is offered as a peace offering to a group or collectivity whose action threatens cherished values of peaceful existence in the society. The action could take the form of violent protests, normlessness or revolution (Henrard 1999).

Whichever form amnesty takes, it generates controversy. There are always divided opinions on the issue of amnesty. Some persons see amnesty as the opposite of justice and it encourages individuals to act out criminal or antisocial behaviour knowing that they will not be negatively sanctioned if they simply stop the behaviour. However, those who opposed amnesty maintain that there is no doubt that if those involved in a revolution are granted amnesty, the war will cease and there be no additional casualties. But justice had eluded those who were already hurt or killed while the revolution lasted. Those who are in favour of amnesty argue that it is easier and cheaper to adopt a strategy that will make the people surrender their fire arms than to confront and punish them (Burke-White 1987, Hadden 2004).

In spite of the controversy associated with amnesty, the rationale behind the granting of amnesty remains viable. The philosophy behind the design of amnesty is to achieve the followings: to alleviate internal pressure, protect state agents from prosecution, promote peace and reconciliation, respond to international pressure, provide reparations, encourage exiles to return and adhering to religious or cultural traditions (Andreas 2002). The Niger Delta amnesty was designed to build peace and reconciliation so as to facilitate the tackling of a wide range package of reform to address the problem of underdevelopment in the region.

\section{Oil Exploration and the Plight of the Niger Delta People.}

The Niger Delta region is naturally endowed with vast oil and gas deposits. The resources attracted the Anglo-Dutch consortium; Shell D'Arcy - a subsidiary of Shell British Petroleum for the purpose of prospecting for crude oil. In a quick succession, other multinational oil companies acquired licenses to also prospect for oil and gas deposits in the Niger Delta. Thus, the Niger Delta became a beehive of crude oil exploratory activities. With the discovery of crude oil in commercial quantity in Oloibiri (present day Bayelsa) in 1956, exploratory activities in the Niger Delta became intensified.

The intensification of exploratory activities contributed immensely to the Nigerian state powering economic growth and development. Apart from its contribution of about 90 percent to Gross Domestic Product, crude oil also accounts for about 95 percent of the expected revenue upon which national budget estimates are based (IMF 2003). With these enormous contributions of the Niger Delta region to national treasury, the indigenes naturally expect that this new economic order will better their lots remarkably by providing employment opportunities, infrastructural development, improved standard of living and above all, sustainable development. This anticipation and enthusiasm is underscored by Madume (1992) who contends that any community that had oil in its earth crust, got their gods sanctified for the unique blessings. 
The most perplexing paradox is that, rather than better the lots of the host communities in the Niger Delta, development is skewed in their disfavour. The overall picture that pervades the region is that virtually all the host communities have one sad tale or the other to share about their miserable experience heaped on them by the multinational oil companies in return for exploiting crude oil in their lands. The inhabitants of host communities generally felt marginalized, cheated and left out in the lurch from the concomitant largesse of contemporary oil revenues. In other words, there is a strong perception of being removed from the concrete realities of a prosperous nation whose financial prowess is continuously rejuvenated from the bowels of their communities.

Apart from the marginalization, the host communities suffer from systematic environmental degradation. The activities of the multinational oil companies came with pains and adverse environmental consequences resulting from unregulated oil and gas exploration. Drilling chemicals such as soda ash, pipe lax, persene drilliad and incessant oil spillages introduce toxicity into the soil and endangered aquatic creatures. The toxicity causes tree defoliation, bark fissuring, seedling mortality, chlorosis, stunted plant growth and general loss of soil fertility. For the aquatic life, there is constant de-oxygenation of the water body which results in asphyxiation of plankson, it also causes the extinction of many aquatic organisms, fishes and other water creatures (Omoweh 2005). The extent of degradation and its destructive effects is aptly captured by the late environmental activist, Ken Saro-Wiwa:

We in Dere, a community in Ogoni today are facing a situation which can only be compared to that of a civil war.... the ocean of crude oil had emerged, moving swiftly like a great flood, successfully swallowing up anything that comes its way; crops, animals, etc....There is no pipe borne water and yet the streams, the only source of drinking water is coated with oil. The air is filled with crude and smells only of crude oil. We are thus faced with a situation where we have no food to eat, no water to drink and no air to breathe (Saro-Wiwa, 1995:14)

The assertion is more or less the sordid environmental realism of host communities in the Niger Delta. Apart from the environmental degradation arising from the exploration, other natural resources are being incapacitated from renewing themselves. The inhabitants are most affected by the activities of the multinational oil companies since most of their economic activities tied to the environment are either disrupted or destroyed. This scenario creates the problem of unemployment, food insecurity and severe deprivations. The people in the face of these predicaments of oil spillage, have to brace up to a hard choice between survival and decimation. The Niger Delta environment is gradually losing its capacity to sustain life. The inhabitants find it extremely difficult to meet the lowest requirements necessary for survival specifically in terms of food, housing, clothing, health and cultural life (Amnesty International, 2009).

The social reality for the inhabitants of the oil bearing communities in Niger Delta is that of helplessness and hopelessness. This becomes worse off as they visualize the enormous petroleum revenues from the bowel of their communities being committed to the development of other regions and the characteristic profligacy of the typical Nigerian politician who fritter away the 'petro-naira' on non profitable ventures. The indigenes began to bemoan the sharp discrepancy in the standard of living and affluence between the oil bearing communities of the Niger Delta and other parts of Nigeria that have no petroleum resources. These negative experiences continuously throw-up the urgent need to address satisfactorily the plight of the Niger Delta people by providing sustainable development in the Niger Delta. The lack of political will to address this fundamental issue by subsequent regimes led to various shades of interminable agitations in the Niger Delta.

\section{Theoretical Underpinnings of the Amnesty Initiative and the Dilemma of Sustainable Development in the Niger Delta Region.}

The theoretical framework that explains the efficacy of the amnesty initiative in providing solution to the problem of underdevelopment in the Niger Delta is the Economic Penetration and Integration Theory of Development. This theory is a variant of the Marxian theories and it is associated with scholars such as Lenin (1933), Schumpeter (1955), Barratt (1974), Hobson (1983), to mention but a few. The theory offers explanation on the penetration or migration of capitalists into the backward regions and be able to influence some members especially the political class, in the peripheral state to legitimize their occupation of viable regions or enclaves in their territory (Offiong 1980).

The rise in organic composition of capital and the decline in the rate of profit, place a dilemma on the capitalist. He cannot opt for oligopolistic competition because it restricts an increase in productivity. Neither can he increase the rate of exploitation because the worker must earn something that is enough to reproduce himself since the continuity of the capitalist business is worthwhile. The decline in the rate of profit was due to excess supply of goods and services and the low purchasing power of the people in the metropolis (Murray, 1973, Ake, 1990).

The most viable option left for the capitalist is redeployment of capital to other lands where the organic composition is still relatively low. In such place of low organic composition of capital, the surplus value per unit 
of labour will be comparatively high because labour is plentiful and therefore, cheap. Thus, as a reaction to the contradictions of capitalists' accumulation, the capitalists from Europe and beyond turned their attention to the economically under exploited Niger Delta region of Nigeria.

Gallagher and Robinson (1953) rightly noted that within a given under exploited region, economic expansion tends to flow into sub-regions of maximum opportunity. The oil rich Niger Delta region to them is a region of maximum opportunity in Nigeria. However, they contend that in the process of integrating a new region into an expanding economy, maximum opportunity depends largely upon political consideration of security as upon the question of profit. Illustratively, they maintain that if economic opportunity seems large but political security small, then full absorption into the extending economy tends to be frustrated until power is exerted upon the region in question. This is in line with O'Connor's argument about imperialists' pre-condition for expansion:

The pre-condition for a truly favourable investment climate is an indirect or direct control of internal politics in the backward regions. Economic penetration therefore leads to the establishment of spheres of influence. (O’Connor 1971:32).

In order to actualize this objective of exerting power, the imperialists resort to the substitution of internal colonialism that Green and Seidman (1968) refer to as false decolonization. Under this arrangement, power is now translated to the domestic ruling classes. In other words, puppet governments represented by stooges and based on some chiefs, reactionary elements, unpopular politicians, big bourgeoisies, compradors or corrupt civil or military functionaries are put in place to run the affairs of the state or region under the control of the imperialists.

These groups of domestic ruling class are what the French so revealingly refer to as the interlocuteur variables meaning negotiators worth talking to (Hall, 1972). These are the local marionettes who will definitely not rock the colonial boat. Their role is to ensure that the basic needs of such societies are ignored and they connive with their colonial masters to promote disunity and disequilibrium in the overall communal social structure, thus frustrating the people's effort aimed at ensuring that the plight of the Niger Delta people is satisfactorily addressed. The Nigerian state can go to any length to make sure that the trauma induced by the activities of the multinational oil companies is not properly addressed.

In order to achieve this, the foreign power brokers represented by the multinational oil companies try to put in place local marionettes that they can negotiate with so as to create conducive atmosphere - devoid of security threat for exploration of the people's resources. This could involve the introduction of a disagreement between community leaders and their subjects. While the community leaders are busy dancing to the tunes of the imperialists, they will be at loggerheads with their subjects. If none of these strategies work, they embark on smokescreen projects and spending strategies by establishing development boards and interventionist agency for host communities such as Niger Delta Development Board (NDDB), Niger Delta Development Authority (NDBDA), Oil Mineral Producing Area Development Commission (OMPADEC), Niger Delta Development Commission (NDDC), to mention but a few aimed at assuaging the minds of the people while multinational oil companies plunder their wealth away through reckless exploratory activities. At the state level, reactionary elements, anti-popular politicians, corrupt civil or military elites are made to emerge as leaders of the Nigerian state. After all, Ogege (2007) rightly observed, that no one in power in Abuja ever wants to lose control of the Niger Delta and its oil and gas resources. Control of power in Nigeria has always been about control of oil revenue. These crops of people who are at the helm of affairs are only interested in what accrues to the Nigerian states and not the harmful impacts of oil exploration on the inhabitants of the host communities in the Niger Delta.

The tactical refusal to address the plight of the people in the Niger Delta, triggered off various shades of interminable violent agitations. Most times, they put in place other institutional measures of violent repression to silence the inhabitants from agitating or asking for equitable and just distribution of the oil revenue derived from their land. The repressive strategies include indiscriminate beating, arrest, detention and even killing by the state security forces. The killing of Ken Saro Wiwa and others show the extent the state can go in trying to pacify the oil companies and making the Niger Delta region conducive for uninterrupted exploration and exploitation of petroleum resources (Ogege 2008). In extreme cases, the ruling class or state managers at the draining end perpetually draft warships and an entire division of army to wipe out any community that is agitating for the underdevelopment problem in the region to be addressed. The genocide in Ogoni land in 1993, Odi massacre of 1999, the Gbaramatu ethnocide of 2009 among others by the Joint Task Force (JTF) point to this fact.

The Nigerian state and the multinational oil companies have realized that the militants have become so resolute in their agitations and are also not deterred by the operations of the military Joint Task Force (JTF). The victory of the military Joint Task Force over the militants in the oil bearing communities did not translate into increased productivity. The state later realized that they lost more oil revenue in the JTF victory than when the militants held sway in the region. For instance, the Nigerian state revenues were adversely affected by the increased violence that heralded the Gbaramatu ethnocide of 2009. The amnesty programme became an inevitable 
response to the inability of the Military Joint Task Force with its heavy artillery and weaponry to ensure a peaceful environment for interrupted exploration and exploitation to raise the revenue base derivable from oil production.

The Nigerian state was desirous to create an enabling business climate for the multinational oil companies to operate unencumbered. What readily comes to mind after due consultation with foreign powers, and the interlocuteur elements- governors and influential traditional rulers in the region was the amnesty initiative. The amnesty initiative was a strategic state policy that is aimed mainly to peacefully but deceitfully dispossess the militants of their arms, take them to camps so that the Niger Delta region remains calm and peaceful for steady and uninterrupted oil production by the multinational oil companies, at the expense of the Niger Delta people (Adejumbi 2009). While the Nigerian state has enough revenue to squander, the Niger Delta predicaments caused by unregulated oil exploration remained unaddressed.

This theoretical perspective sufficiently reveals the motive behind the economic penetration of the multinational oil companies and how they control the internal politics of the Nigerian state and the Niger Delta and destabilize the communal social structure of the people to ensure a favourable investment climate. The theoretical framework also explains how the political consideration of security constitutes a precondition for maximum economic opportunity for the multinational companies in the Niger Delta. This dream can only be actualized through institutionalized amnesty initiative put in place by the managers of the Nigerian state since they realized that the repressive measures were fast becoming counterproductive.

\section{The Imperatives of Peace for the Sustainable Development of the Niger Delta Region}

All over the world, host communities' agitations are common features in regions where multinational oil companies operate below world acceptable exploration standards. Agitations could be confrontational or non confrontational. Those who adopt the confrontational approach employ the use of violence and are mainly youths with different names in different parts of the world. In the Andes Mountains of Colombia and the Amazon region of Ecuador, the agitators are referred to as the Marxist Guerrillas (Zuntie 2000, Watts 2001, Penlikan 2003, Sawyer 2004).

Apart from the early years of oil exploration in the Niger Delta, there have been series of violent agitations. Right from 1956 when oil was discovered in commercial quantity in Oloibiri- a community in Bayelsa till 1965, there were no agitations. The reason for this, among others, is the minimal devastating effect and the anticipation that oil exploration will induce rapid growth and development in host communities. This was also done with the aim then that, as new comers to the region, the oil companies should be given enough time to settle down and develop, thereby removing the stigma of early hostilities by the people of the host communities (Ogege 2010).

Midway into the second decade of multinational oil companies' activities in the region, the people began to experience the travail of crumbling infrastructure, high unemployment, abject poverty etc caused by the destructive impact of oil exploration in the Niger Delta. The devastating impacts of the multinational oil companies witnessed the upsurge of numerous social movements aimed at drawing the attention of the multinational oil companies and the Nigerian state to the plight of the Niger Delta people. The first wind of agitation was that led by Isaac Jasper Adaka Boro, a Kaiama born revolutionist under the auspices of Niger Delta Volunteer Service (NDVS). Since then, several agitations had taken place through the efforts of social movements that adopt non violent strategies - through the issuance of charters and declarations. Some of these social movements are Movement for the Survival of the Ogoni People (MOSOP) that came out with the Ogoni Bill of Rights, Ijaw Youth Council and the famous Kaiama Declaration, the Ikwere came out with the Ikwere Rescue Charter, the Oron people came out with Oron Bill of Rights, the Urhobo nationality came out with the Urhobo Bill of Rights, to mention but a few. A common feature of the agitations is that they are mostly peaceful protests. Despite the non violent agitations, there were intermittent repressions by well armed military outfits. The height of the repression was the use of extra-judicial killing such as the summary executions of the then leader of MOSOP, Ken Saro-Wiwa and eight others by the Nigerian state on 10th November, 1995 by the late Gen. Sani Abacha regime (Ojo 1996)

With the persistent repression and eventual fiendish hanging of Saro-Wiwa and others, it became obvious that non violent agitations cannot compel the Nigerian state and the multinational oil companies to address the burning issues of environmental degradation, wide spread poverty and general underdevelopment of the Niger Delta. Against this background, the Niger Delta youths resorted to the formation of armed militant groups such as Movement for the Survival of the Ijaw in the Niger Delta (MOSIND), Niger Delta People Volunteer Force (NDPVF) and Movement for the Emancipation of the Niger Delta (MEND) (Ikelegbe 2001, Obi 2004). These groups armed with sophisticated weapon of terror, adopt guerilla tactics of confrontation that involves kidnapping of oil workers and sometimes members of their families, seizure and vandalization of oil installations, disruption of the oil production process, and attacking fortified military formations.

In its usual strategy of repression, the Nigerian state deployed the military Joint Task Force (JTF) to the Niger Delta creeks to dislodge the militants. The military Joint Task Force invasion of the Niger Delta resulted in maiming, killing of innocent residents and the sacking of many villages in the region. The most recent incident 
was that of the Gbaramatu Kingdom of Ijaw nationalities in Warri South West Local Government Area of Delta State. The Gbaramatu debacle got to the climax when it was allegedly reported that military men on duty including a major, a lieutenant and 16 others were murdered by the militants under the aegis of Camp 5- a militant outfit led by a militant leader, Government Ekpemupolo, alias Tompolo. In response, the Nigerian state on May 13, 2009 ordered the Army backed by the Navy and Air force to invade Gbaramatu kingdom ostensibly in search of the militants. The indiscriminate ground and aerial bombardment of the military sacked the villages of Kurutie, Oproza, Okerenkoko, Kunukunuma, Kiangbene, Benikurukuru and other communities in Gbaramatu kingdom. Many people including women and children were killed while those who fled became refugees in neighbouring communities.

In spite of the bombardments and casualties recorded, the militants intensified the destruction of oil companies' infrastructure. With this action, the multinational oil companies and the Nigerian state also incurred severe losses. Oil production dropped drastically and the Nigerian economy was crippled. Nigeria's crude oil production per day reduced from 2 million to 800000 barrels per day (Omonobi 2009). It became obvious that the security agents of the Nigerian state could not ensure security in the Niger Delta and oil production precariously hung on a balance as there were series of violent clashes between militants and the repressive agents of the state in various host communities in the Niger Delta. The aftermath is that the militants under the aegis of the Movement for the Emancipation of the Niger Delta (MEND) persistently disrupt oil production in the region.

With the spate of insecurity in the region and the attendant loss incurred by the oil companies and the Nigerian state, Nigerian state realised the imperative of peace in the Niger Delta. Peace in the Niger Delta is the foundation for uninterrupted operation of the multinational oil companies as well as that of sustainable development in the region. Development cannot take place where militancy and conflicts are the order of the day (Ojo 2002, Daniko 2005).

Having exhausted virtually available avenues at ensuring peace in the Niger Delta region, late President Umaru Musa Yar'Adua introduced the Amnesty initiative on June 25, 2009 as part implementation of the 2008 Mittee Committee report. The offer of amnesty was predicated on the willingness and readiness of the militants to give up all illegal arms in their possession, completely renounce militancy in all its ramification within 60 days starting from August 6 and terminating in October 4, 2009. According to its initiator, the amnesty initiative was to restore peace, human and environmental security in the Niger Delta so as to create an enabling environment for accelerated and sustainable development. Against this background, the Presidential Committee on Amnesty was set up to design a framework for the amnesty programme. The amnesty package was designed with three fundamental programmes namely disarmament, demobilization and reintegration (Oyadogha, 2009).

Disarmament refers to the collection, documentation, control and disposal of small arms, ammunition, explosives and light and heavy weapons of destruction. Disarmament in its spectrum, encompasses the development of responsible arms management programmes. Demobilization has to do with the formal and controlled discharge of active combatants from armed forces or other armed groups. It extends from the processing of individual combatants in temporary centres to the massing of troops in camps designated for that purpose. The Reintegration programme incorporates the process by which the ex militants acquire civilian status and gain legitimate and sustainable employment. Each of the programmes has specific time frame (See appendix I)

\section{The Consequences and Challenges of the Amnesty Initiative in the Niger Delta Region}

Between 6th August 2009 when the disarmament (the first phase of the amnesty programme) commenced and October 4, 2009 when it ended, 20,192 militants comprising 20,049 males and 133 females respectively across the nine states of the Niger Delta denounced militancy and registered for the amnesty programme (See Appendix II). Those that accepted the amnesty offer, surrendered their weapons of war to security forces at different designated collection centres. The conditional amnesty offer gave the militants the opportunity to renounce violent agitations. It is worthy to note without equivocation that the amnesty initiative successfully but temporarily put an end to militancy and insecurity in the region thereby paving way for uninterrupted exploration and exploitation by the multinational oil companies.

The remarkable achievement of peace and security has generated considerable goodwill for Nigeria among many international partners and friends. Hostage taking and general insecurity not only affect the nation internally but also a threat to diplomatic relationship between Nigeria and other countries especially home countries of the expatriates that work in the oil companies. Thus, the amnesty programme rebranded and gave Nigeria a positive image among the comity of nations but for the spate of kidnapping for ransom that became pervasive in the south-east geo-political zone of Nigeria.

It is no doubt that the violent agitations of the militants had a negative effect on the economy of Nigeria. The face-off between the militants and the Military Joint Task Force (JTF) and the sacking of the Camp 5 in Gbaramatu, Delta State worsened the economic situation of the country. Although, it was a victory for the Nigerian state, the militants blew up every pipe line on their way as they retreated and faded into the interior creeks. Consequently, oil production plummeted to less than 1 million barrels per day. The state lost more oil production in victory than when the militants held sway in the region (Agbo, 2009). 
With the conditional amnesty granted by the late Yar'Adua's administration, the economic forecast that looked depressed prior to the amnesty offer, began to witness a near instant turn around. The export figures improved from 800,000 barrels per day that it was during the hostilities between 2006 to 2008 to 2.3 million barrels per day in 2010. This increment of 1.5 million barrels per day means that the revenue to national coffers increased by a whopping 120.45 million dollars every day. This enormous wealth was gained as a result of the amnesty programme that brought relative peace into the region.

In spite of the remarkable gains of the amnesty, there are some challenges that the programme has not been able to address.

* The amnesty programme does not incorporate in its packages credible and comprehensive stakeholders' consultation. The opinion of the inhabitants that suffered the brunt of the environmental degradation were ignored. Whatever consultation and endorsement they got were from governors and few traditional rulers who only did not feel the negative impact of oil exploration but also connived with the managers of the Nigerian state to undermine the devastating impact suffered by the people.

* The amnesty initiative is nothing but a militant centered programme aimed at persuasively retrieving firearms from the militants and relocating them to rehabilitation camps where they are placed on monthly allowances. Whatever amount that is paid to the militants will not adequately make up for the life of luxury derivable from illegal oil bunkering activities and ransoms from those taken hostage.

The actualization of peace in line with the amnesty package is on the negative side. The Nigerian state conceived peace as merely the absence of turmoil, tension, conflict and war. Peace on the positive side is conceived as a condition of good management, orderly resolution of conflict, harmony associated with mature relationships, gentleness and love (UNDP 2008). The peace ushered in by the amnesty is devoid of its positive components. For instance, there are cases of protests by repentant militants over the delay and non payment of allowances. The mere fact that the militants carry the label and are addressed as ex-militant negates the principle of amnesty and depicts stigmatization. This has a traumatizing impact on the youths. It accounts for the growing skeptism and fear that the programme is ill motivated (NDCBP 2009).

* The 45 man technical committee on the amnesty was not only on comprehensive disarmament, demobilization and rehabilitation. It also had as its term of reference, the harmonization of various reports on the Niger Delta. The resulting report recommended an increased allocation of oil revenue to the producing communities, urgent improvement of infrastructure and human welfare and new institutions for the region's long-term development. The amnesty as it stands, is only concerned about the symptoms persuading the youths to surrender their arms while the cause which incorporates unemployment, poverty, infrastructural decay and general underdevelopment that affect the generality of people in the Niger Delta are unattended to. This has grave implications for the renewed violent agitations in the Niger Delta.

* The amnesty initiative did not incorporate in its package revenue allocation that is based on derivation as was the case in pre oil economic epoch. If the area that the revenue is derived is not given special consideration by way of fair share, it has great potentials for agitations.

\section{Conclusion and Recommendations}

With the large number of assorted arms and ammunition surrendered by the militants through the amnesty initiative of the late President Yar'Adua's administration, relative peace and improved security situation is now evident. The programme has been able to pave way for the cessation of arm conflict and wanton destruction of lives and properties and other forms of criminality in the Niger Delta region. Emanating from the peaceful and stable environment is the boost in the Nigerian economy through undisrupted and increased oil production. However, the gains of the amnesty are lopsided. They are negatively skewed in disfavour of millions of the inhabitants of the host communities in the Niger Delta. The amnesty initiative is nothing but a militant-centered programme that undermines the plight of the entire Niger Delta people

Whatever benefits that accrue to the people (if at all) only go to the few youths who accepted the amnesty offer, abnegated militancy and surrendered their arms. However, it should be noted that those who renounced militancy constitute a very infinitesimal percentage of the Niger Delta population, so taking them to camp and re-integrating them does not in any way address the problem of underdevelopment in the Niger Delta. The amnesty is silent about the plight of the Niger Delta people that caused and reinforced violent agitations in the region. In other words, the amnesty programme has not been able to remove the people from what Sachs (2005) refers to as poverty trap - a situation in which degraded environment, poor health, poor education, poor infrastructure and poor standard of living reinforce one another.

The neglect of the salient issues that border on the plight of the people, the inconsistency and ambiguities that characterized the implementation of the amnesty programme not only cast doubt on the successful implementation of the amnesty package but it also portends fresh threats to peace in the Niger Delta in a post amnesty era. The fresh militants' attack led by Keiti Sese in Foropa Creek in Southern Ijaw Local Government 
Area of Bayelsa and the face-off between the JTF and John Togo in Eyakoromo in Delta State among others attest to this fact. In order to avert more devastating agitations by the Niger Delta youths, the paper recommends the following as urgent steps to sustainable peace and security in the Niger Delta region:

- The amnesty initiative, though a different and viable approach to the Niger Delta crisis, is not different from other measures in the sense that it has not been able to provide satisfactory solution to the problem of underdevelopment in the Niger Delta. The amnesty initiative addressed only the symptom and not the cause of the Niger Delta problem. Sustainable solutions to the Niger Delta problem must be based on credible stakeholders' consultations and endorsement at all phases and levels. This is grossly lacking in the amnesty initiative. The initiators of the amnesty consulted state governors and few influential traditional rulers. Those who suffer the brunt of environmental degradation must also be consulted. This will enable the Nigerian state appreciate the sustained trauma suffered by the Niger Delta people. With this knowledge, the multinational oil companies and the Nigerian state can address the plight of the inhabitants in a manner that is acceptable to the people.

* There must be credible rehabilitation of the youths that surrendered their firearms. The monthly allowance should be complemented with alternative and viable youth empowerment that can generate their means of livelihood. This could come in form of employment, and grants for small scale businesses. This will enable proper integration into mainstream society and discourage their relapse into militancy. If the amnesty programme is not successfully completed to give room for proper integration and empowerment, the youths could, out of disappointment and frustration, return to militancy.

* The amnesty package should incorporate a holistic framework for sustainable development. This framework should go beyond peace building and pay special attention to sustainable development. The Nigerian state and the multinational oil companies must address issues that border on the environment, infrastructure and the people. Having tackled the security challenges, frantic efforts should be made to encourage community participation and involvement in setting, monitoring and enforcing environmental standards through negotiated agreements backed by local laws and institutions by the oil companies and affected communities. There should also be the availability of infrastructure that can trigger off rapid economic growth and sustainable development.

- The Nigerian state must adopt a fair revenue allocation formula. Those whose communities have abundant oil and gas deposits as natural endowment be compensated with increased derivation allocation of 25 percent as against the current 13 percent. A credible revenue allocation formula as Akpomuvie (2011) rightly noted, represents a viable way of lessening tension, agitations, perception of unfairness and total disillusionment on the part of the inhabitants in the Niger Delta.

* There should be sufficient capacity building and the creation of new jobs through the establishment of labour intensive small scale industries that have high employment elasticity for the age structure of the region's population. If the monumental level of youth unemployment is not taken into consideration, the unemployed youths could be easily persuaded and recruited to use the unsurrendered arms and ammunition to unleash a more devastating round of violence in the region.

* The Nigerian state must desist from compromising its statutory role of ensuring the well being of its citizenry. Striving to create a favourable climate for the multinational companies to operate at the expense of the inhabitants can trigger off disaffection and agitations.

Finally, the effective implementation of the recommendations is anchored on governance that is based on genuine democratic principles of participation accountability and transparency. This will give the Niger Delta the opportunity to choose representatives at all levels of government that will genuinely address the plight of the Niger Delta people and take pragmatic steps that will usher in sustainable development in the region. It is only through this approach that the perennial Niger Delta problem and its attendant violent agitations can be sufficiently addressed. Anything short of this is nothing but a temporary measure aimed at addressing the symptom and ignoring the cause. This could lead to a relapse into more violent agitations in the Niger Delta. This no doubt, is not a favourable situation to the various stakeholders.

\section{References}

Adejumobi, S. (2009). Niger Delta: What Amnesty? The Guardian July 13, p 15

Afinotan, L.A. \& Ojakorotu, V. (2009). The Niger Delta Crisis: Issues, Challenges and Prospects. African Journal of Political Science and International Relations Vol. 3. No. 5

Agbo, A. (2009). The Gains of the Amnesty Programme. Tell November 2, p 18.

Ake, C. (1990). A Political Economy of Africa. New York: Longman Inc.

Akpomuvie, O.B. (2011). Tragedy of Commons: Analysis of Oil Spillage, Gas Flaring and Sustainable Development of the Niger Delta of Nigeria. Journal of Sustainable Development. Vol.4.No 2.pp 200-210.

Amnesty International. (2009). Nigeria: Petroleum Pollution and Poverty in the Niger Delta. London: Amnesty International Publications. 
Andrea, S. (2002). Amnesty for Crime in International Law and Practice. Hague: Kluwer Law International.

Azaiki, S. (2007). Oil Gas and Life in Nigeria. Ibadan: Y-Books Ltd.

Barratt, B.M. (1974). The Economics of Imperialism. Harmondsworth: Merlin Press.

Burke-White B.L. (1987). The Two Sides to Amnesty. Port Harcourt: Sunray Publishers.

Chigara, B. (2002). Amnesty in International Law: The Legality of under International Law of National Amnesty.

Harlow: Longman.

Daniko, P.A. (2005). The Imperatives of Peace in Development. Enugu: Fourth Dimension Books.

Eyinla, P. \& Ukpo, J. (2006). Nigeria: The Travesty of Oil and Gas Wealth. Lagos: Catholic Secretariat of Nigeria.

Gallagher, J. \& Robinson, R. (1953). The Imperialism of Free Trade. Economic History Review, 2(1) p 21.

Hadden, T. (2004). Punishment, Amnesty and Truth: Legal and Political Approaches in Adrian G. (ed), Democracy and Ethnic Conflict: Advancing Peace in Deeply Divided Societies. Palgrave: Macmillan.

Hall, G. (1972). Environmental Poverty Specialty Helps the Poor Fight Pollution. Wall Street Journal, 5(2) p 9.

Henrard, K. (1999). The Viability of National Amnesties in View of the Increasing Recognition of Individual Criminal Responsibility at International Law. Journal of International Law. Vol. 7 pp $595-602$.

Hobson, J.A. (1983). Imperialism: A Study. London: Routledge and Kegan Paul.

Ikelegbe, A. (2001). The Perverse Manifestation of Civil Society: Evidence from Nigeria. Journal of Modern African Studies 39 (1) pp 21.

Ikime, O. (2006). History, The Historian and the Nation. Ibadan. Heinemann Educational Books.

IMF. (2003). Oil Revenue and Budgeting in Nigeria. Official Bulletin No 6.

Lenin, V.I. (1933). Imperialism: The Highest Stage of Capitalism. London: Little Library.

Madume, U. (1992). The Land Use Act. Nigerian Petrobusiness. Vol. 4 p 91.

Murray, R. (1973) Productivity, Organic Composition and the Falling Rate of Profit. Conference of Socialist Economist. Bulletin.

Niger Delta Citizens Budget Platform. (2009). Beyond Amnesty. Port Harcourt: Social Development Integrated Centre.

O'Connor, T. (1971). The Meaning of Economic Imperialism in Fann and Hodges (eds) Readings in US Imperialism. Boston: Porter Sargent.

Obi, C. (2004). Globalization in Nigeria's Oil Industry: Implications for Local Politics in Agbaje A, et al (eds), Nigeria's Struggle for Democracy and Good Governance. Ibadan: University Press.

Offiong, D. (1980). Imperialism and Dependency: Obstacles to African Development. Enugu: Fourth Dimension Publishers.

Ogege, S.O. (2007). Contradictions of Democratic Governance and its Implications for Sustainable Development in the Niger Delta. Nigerian Sociological Review Vol.2 No.1 p 59.

Ogege. S.O. (2008). The State of Multinational Oil Companies and the Dialectics of Agitations in the Niger Delta. Nigerian Sociological Review. Vol. 3.No. 2 p 45.

Ogege, S.O. (2010). A Study of the Relationship between Multinational Oil Companies and Host Communities in Delta State. An unpublished Ph.D Dissertation in the Department of Sociology, Delta State University, Abraka.

Ojo, J.B. (2002). The Niger Delta: Managing Resources and Conflicts. Ibadan: Development Policy Centre.

Omonobi, K. (2009). Niger Delta Crisis: Oil Production Dropped to 800000 barrels Per Day. Vanguard July 8 p 10.

Omoweh, D. (2005). Shell Petroleum Development Company, the State and Underdevelopment of Nigeria's Niger Delta: A Study in Environmental Degradation. Eritrea: Africa World Press Inc.

Oyandogha, S. (2009). Amnesty for Militants as Political Solution to Niger Delta Crisis. Vanguard June 28 p 9

Penlikan, T. (2003). Marxist Guerilla's Agitation. Sheffield: Greenleaf

Sachs J.D. (2005). The End of Poverty: Economic Possibilities of our Time. New York: Penguin Books.

Saro-Wiwa, K.B. (1995). A Month and A Day: A Detention Diary. Harmondsworth: Penguin Books

Sawyer, S. (2004). Crude Oil Chronicles. Durham: Duke University Press

Schumpeter, J.A. (1955). Sociology of Imperialism. London: Meridian Books.

Schey, P.A. (1977). The Pardoning Power and the Value of Amnesty. Journal of Criminology. Vol. 9 pp 325-333. 
Sebba, L. (1997). The Niger Delta: Managing Resources and Conflicts. Ibadan: Development Policy Centre. UNDP. (2006). Niger Delta Human Development Report. Lagos: Perfect Printers

Vanden, K.C. (1998). Amnesty. New York: Kluwer.

Watts, M. (2001). Violent Environments. Ithaca: Cornell University Press.

Zuntie, W.K. (2000). Resource Abundance and Environmental Impact in Colombia. New York: Hyperion.

APPENDIX I: PROGRAMMES OF THE AMNESTY INITIATIVE

\begin{tabular}{|c|c|c|}
\hline DISARMAMENT & DEMOBILIZATION/REHABILITATION & REINTEGRATION \\
\hline $\begin{array}{c}\text { DURATION:AUG 6-OCT } \\
42009\end{array}$ & 6 TO 12 MONTHS & UP TO 5 YEARS \\
\hline KEY ACTIVITIES & KEY ACTIVITIES & KEY ACTIVITIES \\
\hline $\begin{array}{l}\text { Collection of } \\
\text { Arms and } \\
\text { Ammunition, } \\
\text { Explosives, etc. } \\
\text { Documentation } \\
\text { and Biometrics }\end{array}$ & $\begin{array}{ll}\text { - } & \text { Ex-Militants Report to Camp } \\
\text { - } & \text { Verification and Documentation } \\
\text { - } & \text { Transformational Training } \\
\text { - } & \text { Peace Building and Conflict } \\
& \text { Resolution } \\
\text { - } & \text { Counseling } \\
\text { - } & \text { Career Guidance } \\
\text { - } & \text { Wellness Assessment } \\
\text { - } & \text { Reintegration Classification } \\
\text { - } & \text { Education and Vocational } \\
& \text { Placement } \\
\text { - } & \text { Graduation and Demobilization }\end{array}$ & $\begin{array}{ll}\bullet & \begin{array}{l}\text { Knowledge and Skills } \\
\text { Acquisition }\end{array} \\
\text { - } & \text { Financial Empowerment } \\
\bullet \quad & \quad \text { Placement } \\
\text { - Micro-credit } \\
\text { - } & \text { Education } \\
\text { Reconciliation and Local } \\
\text { Community } \\
\text { - } \quad \text { Conflict Resolution } \\
\text { Framework/Mechanism } \\
\text { Monitoring and Evaluation } \\
\text { Exit of Amnesty }\end{array}$ \\
\hline Key Enablers & Key Enablers & Key Enablers \\
\hline $\begin{array}{l}\text { Disarmament } \\
\text { Camps } \\
\text { Massive } \\
\text { Campaign }\end{array}$ & $\begin{array}{l}\text { Transformational Training } \\
\text { Centres } \\
\text { Rehabilitation Camps }\end{array}$ & $\begin{array}{l}\text { Partnering Government } \\
\text { Agencies, NGOs and } \\
\text { Private Organizations, } \\
\text { OGIs. } \\
\text { Tracking and Support } \\
\text { Framework }\end{array}$ \\
\hline
\end{tabular}

Source: Niger Delta Amnesty Programme (2009)

APPENDIX II: PARTICIPANT DEMOGRAPHY

\begin{tabular}{|c|l|c|c|c|}
\hline S/NO & \multicolumn{1}{|c|}{ STATE } & MALE & FEMALE & REGISTERED \\
\hline 1 & Abia & 155 & 8 & 163 \\
\hline 2 & Akwa-Ibom & 571 & 19 & 600 \\
\hline 3 & Bayelsa & 6,900 & 61 & 6,961 \\
\hline 4 & Cross-River & 159 & 1 & 160 \\
\hline 5 & Delta & 3,361 & - & 3,361 \\
\hline 6 & Edo & 450 & - & 450 \\
\hline 7 & Imo & 297 & 3 & 300 \\
\hline 8 & Ondo & 1,198 & 2 & 1,200 \\
\hline 9 & Rivers & $\mathbf{6 , 9 5 8}$ & 39 & 6,997 \\
\hline & TOTAL & $\mathbf{2 0 , 0 4 9}$ & $\mathbf{1 3 3}$ & $\mathbf{2 0 , 1 9 2}$ \\
\hline
\end{tabular}

Source: Niger Delta Amnesty Programme (2009) 